\title{
Wat maak 'n kerkorrel gereformeerd? 'n Verkenning van Afrikaanse 'gereformeerde' musiek in die jare 1980 en 1990 in Suid-Afrika
}

Author:
Cas J. Wepener'
Affiliation:
'Department of Practical
Theology, University of
Pretoria, South Africa
Correspondence to:
Cas Wepener
Email:
cas.wepener@up.ac.za
Postal address:
Private Bag X20, Hatfield,
Pretoria 0028, South Africa
Dates:
Received: 11 Jan. 2012
Accepted: 03 Mar. 2012
Published: 31 May 2012
How to cite this article:
Wepener, C.J., 2012,
'Wat maak 'n kerkorrel
gereformeerd? 'n
Verkenning van Afrikaanse
'gereformeerde' musiek
in die jare 1980 en 1990
in Suid-Afrika', Verbum et
Ecclesia 33(1), Art. \#709,
8 pages. http://dx.doi.
org/10.4102/ve.v33i1.709

(C) 2012. The Authors. Licensee: AOSIS OpenJournals. This work is licensed under the Creative Commons Attribution License.
In this article, the meaning of a combination of the adjective 'reformed' and the noun 'music' is explored. The main question is: What can be termed 'reformed music'? In order to answer this question, some of the work on liturgy by the theologians Smit, Old and McKee will be explored, specifically their understanding of 'reformed liturgy'. Throughout, the article takes the form of a historical reflexive autoethnographic journey into the life and experiences of the author of this article in the period roughly stretching from 1986 to 1996. In particular, it focuses on the way in which the author appropriated two different kinds of music genres. His exposure to both reformed church music and the alternative Afrikaans music movement, which included rock bands such as Johannes Kerkorrel en die Gereformeerde Blues Band will be scrutinised. Ultimately, the aim of this journey is to establish which one of these two music genres from this specific period in the history of South Africa is worthy of the name 'reformed music'.

\section{Inleiding}

In hierdie artikel wil ek deels hand in eie boesem steek. Ek onderneem hier 'n soort terugskouende outo-etnografiese verkenning wat gekomplimenteer word met relevante literatuur. Die navorser of etnograaf is ekself en die objek van studie is deels ook ekself, maar spesifiek die navorser in verhouding tot twee soorte musiek, te wete kerkmusiek soos wat dit voorgekom het in Nederduits Gereformeerde (NG) eredienste wat ekself bygewoon het en alternatiewe Afrikaanse musiek. Gevolglik sal ek my herinneringe en belewenisse met betrekking tot hierdie musiek ondersoek, spesifiek ook ten opsigte van die invloed wat hierdie twee soorte musiek in my lewe gehad het (en steeds het). Daarmee saam neem ek ook as objek van studie die betrokke musiek self. Die tydperk waarna ek hier verwys, is so rofweg tussen 1986 en 1996, my hoërskooljare op George in die Suid-Kaap en 'n deel van my studentejare op Stellenbosch. In daardie jare was ek amper elke Vrydag in 'n kuierplek, elke Sondag in die kerk en vir die res van die week was sowel kerk as kuierplek deel van my lewe. Dit het ook gegeld vir die musiek wat by elkeen gepas het. Beide soorte rituele klank en taal ${ }^{1}$, spesifiek hier die melodieë en lirieke, van die onderskeie ruimtes het my hart en verstand aangespreek en vormend op my ingewerk in wie ek geword het, en steeds aan die word is. Dit is hierdie vormende invloed wat ek kortliks in die bestek van hierdie artikel wil verken en daardeur spesifiek ook die begrip 'gereformeerde musiek' krities wil belig.

My navorsingsvraag is: Watter een van hierdie twee spesifieke musiekgenres waaraan ek blootgestel is, kan as 'gereformeerde musiek' beskryf word. Die keuse val hier tussen die gereformeerde kerkmusiek (veral die gemeentesang) van die eredienste en ander kerklike byeenkomste wat ek bygewoon het en die alternatiewe Afrikaanse musiek soos dié van Johannes Kerkorrel en die Gereformeerde Blues Band en ander wie se konserte ek bygewoon het en na wie se kassette ek geluister het? Ten einde hierdie vraag te verken, sal enkele stappe geneem word.

Na enkele opmerkings rakende die metodologie van die studie sal verskeie vensters oopgemaak word om lig op die vraagstelling te laat val. Daar sal ongelukkig in so 'n aanpak geensins by 'n netjiese pasklaar antwoord uitgekom word nie, alhoewel die kompleksiteit van die vraagstelling hopelik beter uit die verf sal kom. ' $n$ Eerste venster sal ' $n$ beskrywing behels van die twee soorte musiek uit hierdie jare soos ek dit self beleef het. Die volgende venster sal die raadpleeg van teologiese en liturgiese literatuur behels wat verdere lig kan werp op die konsep 'gereformeerde musiek'. Hiervoor sal spesifiek aangeklop word by drie gereformeerde teoloë en hulle verstaan van die begrip 'gereformeerde erediens'. Hierdie teoloë se insig kan help om die begrip 'gereformeerde musiek' beter te belig en daardeur ook om uiteindelik tot 'n eerste beoordeling te kom van die musiek wat deels as objek van studie in hierdie artikel dien. Die volgende

1.Ronald Grimes (1995:24-38) onderskei tussen ses kategorieë, te wete rituele ruimte, rituele objekte, rituele tyd, rituele klank en taal, rituele identiteit en laastens rituele handeling. 
venster behels ' $n$ herbesoek aan die musiek self. Hier sal ander materiaal ( 'n DVD, kompakskywe, kassette, artikels en boeke) wat oor die twee soorte musiek handel en dit ook bevat in die verkenning betrek word. 'n Laaste venster sal 'n kort verkenning van die identiteitsvormende potensiaal van die twee soorte musiek en veral die lirieke self wees wat terugskouend refleksief-etnografies aan bod gestel sal word. Ten slotte sal 'n oordeel gefel word om te kyk watter een van hierdie twee tipes musiek, te wete Afrikaanse Nederduitse Gereformeerde (NG) kerkmusiek of alternatiewe Afrikaanse musiek uit die genoemde tydperk - of miskien beide of geeneen - werklik beskou kan word as 'gereformeerde' musiek in die tydperk wat in hierdie artikel gedek word.

\section{Metodologiese oorwegings}

Etnografie is 'n metode van data-insameling wat tradisioneel in dissiplines soos die Kulturele Antropologie en Sosiologie gebruik word om mense van ' $n$ bepaalde kultuur te bestudeer. Basies kom die taak van die etnograaf daarop neer om die data te versamel, daaroor te rapporteer en dit ook te evalueer. ${ }^{2}$ As metodologie maak die etnografie veral gebruik van onderhoude en deelnemende observasie ${ }^{3}$ om die data te versamel. Van vroeg af - en juis ook op grond van die werk van 'n baanbreker-etnograaf en kulturele antropoloog, Bronislav Mallinowski, op eilande onder kulture in die Stille Oseaan wat vir baie Westerse antropoloë vreemd en onbekend was - is die problematiek wat te make het met die posisie van die etnograaf as deelnemende observasie ingesien, aangesien iets soos ' $n$ neutrale waarnemer onmoontlik is. ${ }^{4}$ Met verloop van tyd het daar ' $n$ soort evolusie in etnografie gevolg wat saamhang met die verskuiwing in belangstelling vanaf vreemde veraf kulture na kulture wat nader is aan eie huis soos hospitale en skole in 'n ondersoeker se eie land:

Reviewing the history of this research tradition, then one can perceive a particular thread of ethnography as evolving from an exploration of the lifeworlds of those most foreign to the research through investigations that touched closer to home by examining the worlds of those living within the researcher's own society, to studies that explore the lifeworlds of the researchers themselves. (Duncan 2004:3-4)

Hierdie historiese ontwikkeling bring ons by die sogenaamde outo-etnografie. Outo-etnografie is 'n omstrede metode aangesien die navorser tegelyk subjek en objek van die navorsing is, en gevolglik gekritiseer word as te individualisties en introspektief (Duncan 2004:2). Outoetnografie word dikwels gebruik as 'n soort kortpad wanneer die tyd en fondse vir 'n volwaardige etnografiese studie wat maande en selfs jare behoort te duur, ontbreek en fokus dikwels op 'n waarneming en noukeurige dokumentering van die navorser se eie gedrag. ${ }^{5}$ Vir hierdie ondersoek sal tereg

2.Kyk spesifiek na Babbie en Mouton (2001:279-280), maar vir algemene inligting oor etnografie en veldwerk ook na Bailey (1996), Reason (1994) en Stewart (1998). Vir meer inligting oor liturgiese musikale etnografie, kyk na McGann (2010).

3.Kyk in hierdie verband en toegespist op liturgiese navorsing na die volgende bronne: Johnson (2005), Stringer (1989 \& 1999) en Wepener (2005, 2009 \& 2010). Vir ' $n$ meer algemene werk in die veld van die sogenaamde Ritual Studies, kyk na Stephenson (2010).

4.Vgl. ook Bell (1997).

5.Cunnigham en Jones (2005) gebruik outo-etnografie byvoorbeeld om eie gedrag in die gebruik van elektroniese apparatuur te dokumenteer aangesien dit baie sal ooreenstem met dié van die gebruikers van die apparatuur. Die doel daarvan is om ooreenstem met die van die gebruikers van die apparatuur. Die doel daarvan is om
sodoende die ontwikkeling van hierdie apparatuur met die oog op die gebruikers te verbeter. gevra kan word of daar in hierdie artikel outo-etnografies, refleksief-etnografies of gewoon net outobiografies te werk gegaan word. In hierdie artikel word die term outoetnografie gebruik, alhoewel die ander verwante konsepte ook gepas sou wees. 'n Refleksiewe verslag van eie ervaringe word hier aangebied, alhoewel die verslagdoening in hierdie artikel merendeels histories van aard is. Dus moet bykomend tot die outo-etnografiese benadering gemeld word dat die benadering verder terugskouend is en die verslagdoening en onthouproses van die outeur gebaseer is op sy 'ervaringswaarheid'6 eerder as 'n objektiewe feitlike verslagdoening.

Ten einde dit enigsins verantwoordelik te kan doen, sal ander stemme in die verhaal ingenooi word. Spesifiek sal gekyk word na boeke en artikels wat oor die sogenaamde Voëlvry-beweging handel. Dit sluit werke in soos Die tyd van die kombi's deur Koos Kombuis (2009) en verder ook 'n DVD getiteld Voëlvry die movie wat oor die Voëlvry-toer gemaak is, asook enkele ander artikels in nuusblaaie en op die internet wat oor die onderwerp handel. Hier is dus sprake van triangulasie om my eie ervaringswaarheid ten dele onder kruisverhoor te neem. ${ }^{7}$ Vervolgens word eers 'n voëlvlugtoer oor die outeur se 'voëlvry'-ervarings aangebied om die agtergrond vir hierdie verkenning te skets alvorens die begrip 'gereformeerde erediens' verken word.

\section{Agtergrond}

Dit is 1987 en ek is in standerd 7 (graad 9). Ek stap by die plaaslike musiekwinkel in en ontdek 'n kasset getiteld Vêr van die ou Kalahari (Le Toit 1987) deur 'n ene André le Toit. Ek is dadelik gefassineer deur die titel van die liedjies agterop die omslag, byvoorbeeld Ontug in die lug, Boer in beton en Swart Transvaal. Die grootste deel van my familie is Nasionaal, ekself het nie ' $n$ besonder sterk ontwikkelde politieke bewussyn nie, maar vermoed al 'n tyd lank dinge is nie alles pluis in die land nie. Ek sê dit sonder om myself in retrospek as 'n politieke held te skets wat ' $n$ proses van selektiewe amnesie sal behels - verseker nie 'n onbekende verskynsel onder Suid-Afrikaners nie. Alles behalwe - ek was Wit, bevoorreg en vol vooroordele, alhoewel rasseverhoudinge my wel ongemaklik gemaak het, soos vir baie ander Wit Suid-Afrikaners in daardie dae. Daardie belewenis was deel van my naïewe jong identiteit en voeg seker daarby so 'n skeutjie van die asprisgeit van 'n tienerseun. Die punt is, my gewaarwording het veroorsaak dat ek gehou het van dit wat ek daar agterop die kasset gelees het. Ek het dus my geld, wat ek in die Spur verdien het, gebruik en vir die volgende drie jaar onophoudelik op my kassetspeler na Vêr van die ou Kalahari (Le Toit 1987) geluister met versreëls soos:

6.'Ervaringswaarheid' is 'n term wat aan Deist (1997:2) ontleen word. Met hierdie begrip het hy die tipe waarheid beskryf waarom dit by die Waarheid en Versoeningskommissie (WVK) gegaan het. Daarmee het hy bedoel dat die tipe waarheid anders is as die waarheid waarom dit in 'n hofsitting gaan. 'Dit wil sê maarheid anders is as die waarheid waarom dit in " $n$ hofsitting gaan. 'Dit wil se mense kom vertel hulle verhale uit hulle perspektief en volgens hulle interpretasie van wat gebeur het'. Die sogenaamde'ervaringswaarheid' van die WVK is dus die vertelde verhale in teenstelling met waarheid in die regstegniese juridiese sin wat
onder kruisverhoor getoets word. Vgl. ook Wepener (2004:93).

7.Koos Kombuis se boek Die tyd van die kombi's is ook gegrond op sy eie ervaringswaarheid en het as sodanig al hewige kritiek van ander belanghebbendes in die Voëlvry-beweging, soos Dagga Dirk Uys, ontlok. 


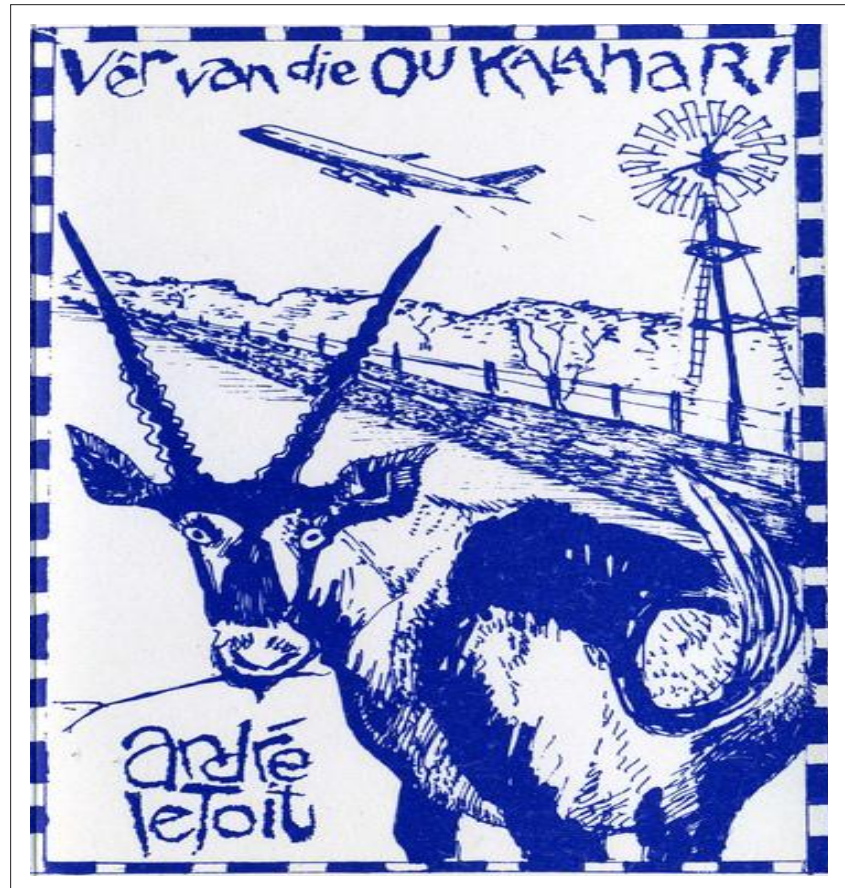

Bron: Flickr, 2012, Andre Le Toit - Ver Van Die Ou Kalahari, besigtig op 28 Maart 2012, van http://www.flickr.com/photos/anjinsan/2541257471/

FIGUUR 1: Omslag van die album album getiteld Vêr van die ou Kalahari, vrygestel in 1989 deur Shifty Records.

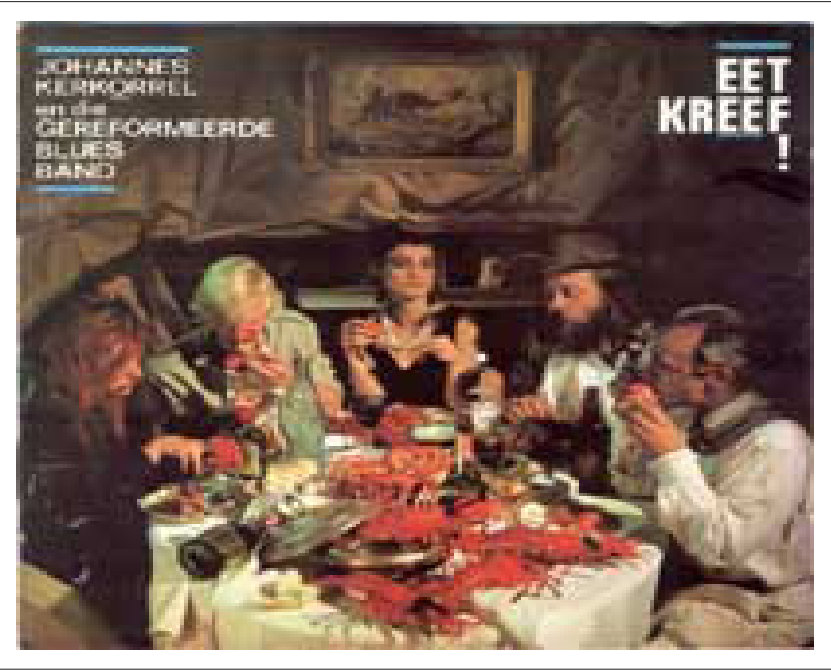

Bron: The South African Rock Encyclopedia, 2012, Johannes Kerkorrel, besigtig 28 Maart 2012, van http://www.rock.co.za/legends/90s/kerkorrel_index.html

FIGUUR 2: Omslag van die album getiteld Eet kreef!, vrygestel in 1989 deur Shifty Records.

My meisie dra 'n pasboek in 1984

sy sê vir my djou askoek

ek sê vir haar jy's pragtig

want daar is ontug in die lug

ontug onder die brug (Strofe uit Ontug in die lug vanaf die album Vêr in die ou Kalahari)

In die jare wat gevolg het, het my versameling uitgeberei met albums soos Eet kreef! deur Johannes Kerkorrel en die Gereformeerde Blues Band. In hierdie tydperk was daar natuurlik baie ander musiek waarna ek onvermydelik ook geluister het, soos A-HA, Dire Straits en U2, om maar enkeles te noem.
Tog, benewens André le Toit (Koos Kombuis) in hierdie vroeë jare, was die orrel-begeleide gemeentesang uit die Psalm- en Gesangeboek ${ }^{8}$ op Sondagoggende en die kitaarbegeleide liedere uit bundels soos die Jeugsangbundel tydens jeugbyeenkomste by die NG Moederkerk, die tweede belangrike vormende musikale faktor in my lewe. Met ander woorde, hierdie kerkmusiek het verseker ook ' $n$ groot vormende invloed uitgeoefen op wie ek aan die word was. Wanneer daardie orrel oopgetrek is en honderde wit lidmate gesamentlik opgestaan en uit volle bors gesing het O God van Jakob of Juig al wat leef of Diep, o God, diep neergeboë (dis die eerste drie wat terugskouend by my opkom en dit is as sodanig seker ook nie sonder betekenis nie) dan het jy geweet dit is goed om deel van hierdie groep mense te wees; wat onder andere beteken het dis goed om ' $n$ Wit persoon en NG te wees. As ek vinnig moet dink aan emosies en gewaarwordinge wat gedagtes aan daardie musiek retrospektief by my oproep, sal die adjektief 'geborgenheid' dit seker die beste opsom.

Enkele jare later sou nog meer alternatiewe Afrikaanse musikante my oortromme laat vibreer en terselfdertyd sou hulle krake in my identiteit veroorsaak (miskien was dit krake waardeur 'n bietjie lig kon skyn). Hulle musiek het mettertyd ook' $n$ soort ongemak in my aangewakker rakende my identiteit as genieter en saamsinger van Psalms en Gesange met orrelbegeleiding en al die teologiese aansprake wat die woorde gemaak het. 'n Groep soos Randy Rambo en die Rough Riders het met hulle lied Jong Dames Dinamiek hierdie spanning goed beskryf. Ek kon my eie ongemak goed daarin terughoor en die spesifieke ritme en soort marsagtige musiekbegeleiding wat hulle ingespan het, het ook iets van die verbeeldingloosheid en gedwongenheid van al die aannames wat met Afrikanerskap en Christenskap saamgegaan het, goed uitgedruk. Die eerste paar reëls uit Jong Dames Dinamiek dien ter illustrasie (lees dit met staccatoagtige marsmusiek in gedagte $)^{9}$ :

ons huis is massief en ons kar baie blink ons swembad is groot en die tuinjong so flink die dahlias blom mooi en die kinders is soet hulle hou ons naam hoog as hul oom dominee hoflik groet

en ons eet en ons drink en ons werk en ons bid en ons slaap en ons swem en ons teel en ons sit ('n Uittreksel uit Jong Dames Dinamiek vanaf die album Voëlvry)

Natuurlik was André le Toit se Swart Transvaal en sy sarkastiese blik op Afrikaners en hul (ons) godsdiens van destyds onoortreflik, byvoorbeeld:

In die glasruite van aande
weerkaats die laaste maande
skimme van 'n ou beskawing
voor ons kerkgeslag se sondes

en later

Want die erwe van ons vaad're sal vir plotte teen ons kinders tel

8.Spesifiek Serfontein et al. (reds.) (1976).

9.Die lied Energie van Johannes Kerkorrel en die Gereformeerde Blues Band sou goedskiks oor hier ter illustrasie kon dien. 
vars grond, bloed grond tuimel in

ideale val soos Carltonville

ondergronds is God die hel in

vir die Boerenasie

wat bid soos Fariseërs

maar nooit wil ophou rasie (Le Toit 1988:81-82)

En toe in 1989, heelwat eredienste en Kerk-Jeug-Aksie (KJA)-byeenkomste later, is daar as deel van 'n sogenaamde Voëlvry-toer ' $n$ konsert in die Burgersentrum van George gehou . Ek en enkele vriende het met denims en lang swart jasse die bekende kwasi-heilige ruimte van George se Burgersentrum ingeloop. Die ruimte waar ons gewoonlik aan redenaarskompetisies deelgeneem het of vir beoordelaar-tannies gediggies op eisteddfods opgesê het en waar P.W. Botha vir sy getroue George-ondersteuners tydens verkiesings kom handdrukke gee het (het self op my dag in die spesifieke ruimte die voorreg gesmaak). Binne in my het daar onvermydelik en oombliklik ' $n$ soort herraming ${ }^{10}$ ten opsigte van George se Burgersentrum plaasgevind, want op die verhoog was daar letterlik portrette van Afrikanerdomrelikwieë soos geraamde prente van proteas wat vanaf die dak op die verhoog gehang het om te waak oor 'n verhoog waar kitare en mikrofone 'n ossewa omring het. Die boodskap was duidelik - ons aannames oor wie en wat Afrikaners is, sal hier aan flarde geskiet word. Daar was 'n vreemde opwinding in die lug, 'n atmosfeer was aan die opbou en ek het geweet hierdie is die 'erediens' waarvoor ek gewag het sedert daardie eerste keer toe ek na Vêr van die ou Kalahari (Le Toit 1987) geluister het. André le Toit het opgetree, so ook Johannes Kerkorrel en die Gereformeerde Blues Band en nog groepe waaroor ek nie doodseker is nie. Volgens Koos Kombuis (2009:128-144) ${ }^{11}$ was Bernoldus Niemand en Randy Rambo en die Rough Riders (soms ook bekend as die Naaimasjiene) ook deel van die toer, en dus bes moontlik van die ander kunstenaars wat opgetree het.

Nietemin, sommige van hierdie musici het op hulle eie spottende manier die adjektief 'gereformeerd' vir hulself toegeëien, soos Johannes Kerkorrel en die Gereformeerde Blues Band, ' $\mathrm{n}$ adjektief wat tradisioneel elders tuishoort. Wat hulle egter reggekry het, was dalk 'n soort reformasie of hervorming, of was dit 'n revolusie of 'n blote poging om anargie te saai? Wat is die verskil tussen al die begrippe en sou 'gereformeerd' en 'kerkorrel' net as spottend beskou kan word, of was Ralph Rabie (Johannes Kerkorrel) en kie se naamkeuse miskien meer gepas as wat hulle besef het? Op hierdie punt is dit nodig om eers hierdie konsep in meer besonderhede te verken.

\section{'Gereformeerde' erediens (en lied)}

In 'n hoofstuk getiteld 'Ontdek die eie aard van die Gereformeerde erediens' bespreek Smit (2009:87-107) die

10.Vgl. Capps (1990:17) wat Watzlawick, Barelas en Fisch se definisie van 'reframing aanhaal, naamlik 'to change the conceptual and/or emotional setting or viewpoint in relation to which a situation is experienced and to place it in another frame which fits the 'facts' of the same concrete situation equally well or even better, and thereby changes its entire meaning'.

11. Hierdie gedeelte van die boek handel spesifiek oor die Voëlvry-toer. Vergelyk hier gerus ook die tweede lang paragraaf op bladsy 133 waar die verloop van die hele konsert beskryf word en waar die beskrywing amper klink soos die verloop van ' $n$ tipiese liturgie in ' $n$ meer charismatiese kerk. konsep 'gereformeerde erediens'. Hy maak eerstens 'n aftreksom van wat sommiges dink die kombinasie van die adjektief 'gereformeerde' en selfstandige naamwoord 'erediens' wel beteken, maar inderwaarheid volgens Smit nie is nie, byvoorbeeld dat sekere liturgiese praktyke se aan- of afwesigheid in ' $n$ erediens sal bepaal of ' $n$ erediens 'gereformeerd' is al dan nie. Uiteindelik kom hy dan tot sy gevolgtrekking wat 'gereformeerde erediens' wel beteken, naamlik dat dit in essensie gaan oor die 'aard van God se teenwoordigheid' (praesentia realis) en die 'aard van die teenwoordige God' in die erediens en die 'aanbidding van die teenwoordige God'. In my verstaan van Smit se hoofstuk is daar ' $n$ kontinue hermeneutiese proses in die begrip 'gereformeerde erediens' ingebou, wat beteken dat 'n erediens wat die adjektief 'gereformeerd' waardig is, 'n erediens is waarbinne die voortgaande veranderende konteks of leefwêreld van erediensgangers en die boodskap van die Skrif en tradisie voortdurend in afhanklikheid van die leiding van die Heilige Gees met mekaar in verband gebring word en dan as sodanig liturgies tot uitdrukking kom. ' $\mathrm{n}$ 'Gereformeerde erediens' is dus, met inagneming van die Skrif, tradisie en konteks, 'n voortdurend reformerende erediens

In lyn met Smit se denke staan die Amerikaanse Gereformeerde liturgis, Old (2002), se boek getiteld Worship. Reformed According to Scripture. Vir Old is die aard van die Gereformeerde erediens ten diepste ook 'n hermeneutiese aangeleentheid, te wete dat dit ' $n$ voortdurend reformerende gegewe is wat sigself aan die Bybel oriënteer. Daar is volgens Old daarom nie so iets soos die gereformeerde tradisie (of erediens, of lied) nie, alhoewel daar wel sekere aantoonbare waardevolle bydraes bestaan wat uit spesifiek die gereformeerde liturgiese tradisie afkomstig is. Volgens Old (2002:176) is die grootste enkele bydrae 'its sense of the majesty and sovereignty of God, its sense of reverence and simple dignity, its conviction that worship must above all serve the praise of God'.12

McKee bevestig hierdie klem in Calvyn se denke, naamlik die sentrale belang van die doksologie in aanbidding. Calvyn se verstaan van aanbidding en liturgie moet egter binne die breër raamwerk van sy teologiese denke geplaas word. Dit behels onder andere dat die konteks van diakonia vir Calvyn aanbidding is en '[F]or Calvin, trust in God alone and offering oneself to serve God and the neighbor are the right worship, the true sacrifice of Christians' (McKee1995:180). Sy (McKee1995:181-185) wys verder op die belang van die verhouding tussen die gebod rakende die liefde vir God (pietas) en die liefde vir die naaste (caritas) in aanbidding. Hierin geniet die pietas voorrang maar dit word deur die caritas getoets. Hierdie onderskeid staan sentraal in Calvyn se verstaan van aanbidding. Pietas en caritas en die aard van die verhouding tussen die twee behoort dus deel te vorm van 'n kriterium wat kyk na wat onder 'n 'gereformeerde' erediens en musiek tuishoort al dan nie.

12.Vgl. ook Wepener (2008:313-335). Vir verdere verkennings van die begrip 'gereformeerde erediens', kyk ook na McKee (1995 \& 2003). 
Ek volstaan hier met hierdie drie teoloë se bespreking van die konsep om daarmee slegs aan te toon dat die betekenis van die begrip 'gereformeerde erediens' nie so heel voor die hand liggend is nie. Die bepalende faktore vir wat as 'gereformeerde' musiek of 'n 'gereformeerde' lied of selfs 'gereformeerde' klank sou kon kwalifiseer, is dus ook nie so eenduidig nie. Hierdie opmerking behoort ook voorlopig aan te toon dat 'n keuse vir musiek waarvan die oorsprong in die destydse Psalm- en Gesangeboek is en binne die kader van 'n NG erediens in 'n Protestantse kerkgebou uitgevoer is, nie noodwendig as 'gereformeerde' musiek beskou kan word nie.

In die tydperk wat deur hierdie artikel gedek word, het die Algemene Sinode van die NG Kerk van 1994 ook 'n skrywe goedgekeur getiteld 'Riglyne vir kerksang en -musiek'. Hierdie riglyne stel dat die wesenlike verskil tussen sang in die kerk en die wêreld is dat 'die Bybel se inhoud en boodskap' in alle kerksang deurslaggewend is. Die binding van die kerklied en -musiek met die Bybel word in hierdie riglyne as sentraal aangebied, maar stel dit wel duidelik dat dit ook gaan oor die boodskap van die Bybel. In die lig hiervan word die boodskap van die Bybel verduidelik as, onder andere, die groot dade van God, en dat daardie dade in die kerklied gedenk en herbeleef word. 'Deur te sing, eien die gelowiges hulle dit toe en altyd weer toe' (Algemene Sinode van die NG Kerk 1994:402). Daarom kan die riglyne dit ook later stel dat die Bybelse inhoud en boodskap in die lied op die konkrete mens hier en nou in sy en haar leefwêreld afgestem moet word (vgl. Algemene Sinode van die NG Kerk 1994:402-403).

Hierdie sinodale riglyne, teen die jaar 2012 steeds die geldende riglyne vir kerkmusiek in die NG Kerk, saamgelees met Smit, Old en McKee se werk, wys duidelik dat die kriterium vir wat presies 'gereformeerde' musiek is, iets is wat baie moeilik bepaalbaar is. Aan die een kant is daar die vereiste om kontekstueel te wees en aan die ander kant die vereiste om Bybelgetrou te wees. Die twee tafels van die wet, liefde vir God en liefde vir die naaste, moet verder deurlopend in die oog gehou word. Die vraag is egter waar die grense van Bybelse kontekstualisering en Skrifgetrouheid en die liefdesgebod in kerkmusiek getrek moet word.

\section{Twee 'gereformeerde' kerkorrels, twee bekerings}

Gedurende 'n mens se hoërskooljare is jy besonder vatbaar vir bekerings. Ek het die voorreg gehad om verskeie hiervan te beleef, maar sonder vir die doeleindes van die artikel twee daarvan hier uit. Die een bekering het in verband gestaan met die alternatiewe Afrikaans musiek-beweging, deels vanweë my blootstelling aan die musiek, deels vanweë 'n groeiende bewuswording van die onreg van apartheid en deels vanweë die besondere sosiaal-maatskaplike konteks waarin ek geleef het. Hier kan'n mens maar net dink aan die oproep tot bekering wat uitgaan in 'n reël soos 'gee jou hart vir Hillbrow', spesifiek ' $\mathrm{n}$ bekering tot meelewing en hulpverlening aan diegene in nood. Die ander bekering was die soort wat op verskeie KJAkampe goed bedoeld geïnduseer is en in verband gestaan het met ' $n$ belydenis van Christus as persoonlike Verlosser en die daaruit voortvloeiende geloofsekerheid. ${ }^{13}$ Beide hierdie bekerings was nie eenmalige gebeure nie, maar duur steeds voort, alhoewel hulle in my eie persoon tot ' $\mathrm{n}$ groot mate vervloei het en vandag moeilik te onderskei is. Die lyn tussen die oproepe 'gee jou hart vir Christus' en 'gee jou hart vir Hillbrow' is vandag vir my vaag, so vaag soos die lyne tussen liturgie en lewe in 'n Gereformeerde verstaan van die erediens ook behoort te wees.

In die hoofstuk wat spesifiek handel oor die Voëlvry-toer van 1989 waarvan ekself, soos reeds genoem en beskryf, die een konsert bygewoon het ${ }^{14}$, skryf Koos Kombuis heelwat oor Johannes Kerkorrel as kunstenaar. Volgens Koos Kombuis (2009) was Johannes Kerkorrel uitstaande in sy verhoogoptrede. Wanneer hy oor Kerkorrel se verhoogoptredes tydens die toer skryf, neem Kombuis se taalgebruik onmiskenbare religieuse kwaliteite aan. Eintlik sou ' $n$ mens kon sê dit neem liturgiese kwaliteite aan waarbinne die lied in die besonder en klank in die algemeen natuurlik 'n integrale plek inneem. Die volgende is ' $n$ voorbeeld hiervan:

Orals waar hy (Johannes Kerkorrel) gaan, verlos hy mense van die demone van Calvinistiese skuldgevoelens en Nasionalistiese rassisme, hy maak hulle oop vir die wonderlikste nuwe emosies, hy weet presies hoe om sy web van landswye muitery te spin, hy verkondig die waarheid hard en duidelik, hy verkondig die evangelie waarna die jeug smagtend op soek was tot nou toe. (Kombuis 2009:178)

Die waarheid van hierdie soort beskrywings kan ek beaam. Hierdie konsert was vir ons en spesifiek vir my veel meer as net ' $n$ musiekkonsert. As ' $n$ konsert het dit liturgiese kwaliteite en die soort rituele dimensies gehad wat die liturgis Gerard Lukken ${ }^{15}$ beskryf. Vir my was dit 'n oomblik van insig (daar is baie mense in ons land wat anders dink) en as sodanig het dit ' $n$ gemeenskapstigtende dimensie gehad (ek is nie die enigste ketter nie en ander leerders in my skool en selfs ons skool se Engelse onderwyser het die konsert baie geniet). Die hele aand was verseker terapeuties (om op die ritme van Ossewa dansend rond te spring, is bevrydend) en deelname aan hierdie ritueel was ook beswerend, want diegene met die politieke mag het nie die laaste sê in ons land nie! Koos Kombuis (2009) beskryf Johannes Kerkorrel se optrede verder op 'n trefsekere wyse:

Wanneer hy ' $n$ hallelujalied soos Wat ' $n$ vriend het ons in Jesus opstuur met nuwe woorde, wil jy saam met hom lag, hard en sardonies en alwetend:

Wat ' $n$ vriend het ons in P.W.

Vlok en Heunis en Malan...

Nadat jy 'n Kerkorrel-show gesien het, wil jy opstaan en getel word. Jy voel die gety van hoop naderstu, jy kan jouself verbeel

13.Kyk in hierdie verband na die hoofstuk getitel Bevry van 'geloofsekerheid' in Müller (2011:25-41).

14.In die jare tussen die konsert op George in 1989 en 1996 het ek verskeie optredes van hierdie kunstenaars meegemaak.

15.Vgl. Lukken (1999:58-70) vir onder andere die kanaliserende, etiese, beswerende en politieke dimensies om maar enkeles uit te sonder. 
as deel van die nuwe Suid-Afrika wat besig is om gebore te word, onafwendbaar. Jy is lus om vir die heersende magte te sê: Ons het julle ware gesigte gesien. Ons glo julle stories nie meer nie. Ons is moeg vir julle leuens. Ons het deur julle fasade gekyk, want Kerkorrel het die spieël voor ons gesigte gehou sodat ons julle kan herken vir wie julle regtig is. (n.p.)

Die aanwesigheid van die klassieke liturgiese en sakramentele anamnese $^{16}$ is sterk in hierdie taalgebruik teenwoordig. Die land, spesifiek die Afrikanervolk, se baie onlangse en steeds heersende verstaan van die verlede of geskiedenis is gedurende so ' $n$ konsert, dus in die toenmalige hede, met die oog op die toekoms onthou. In hierdie anamnetiese proses is nuwe moontlikhede oopgebreek, moontlikhede wat gewoon net anders was as die status quo.

Desnieteenstaande, as ek nou konsekwent en eerlik moet bly, het die Sondag-eredienste en KJA-byeenkomste ook bogenoemde kwaliteite vertoon, alhoewel op 'n ander wyse. Die bedoeling om skuld te bely en daarvan bevry te word, is seker ten beste verwoord deur Gesange soos Diep, o God, die neergeboë, wat die gemeente op die genadeverkondiging voorberei het. Eweneens was al die Lofpsalms en -gesange, die lament van die lydensliedere of die uiting van dankbaarheid, geloof en hoop voorwaar ook in eie reg terapeuties. Behalwe vir die rubriekindeling van die Psalm- en Gesangeboek wat spesifiek oor die kerklike jaar van Advent tot en met Koninkryk(tyd) handel, is die ander rubriekindelings eers trinitaries gerangskik en daarna volg die algemene indelings van 'Kerk en Erediens' en 'Algemene Gesange'. ${ }^{17}$ Ook in die sing van hierdie liedere, in die opvoering van die heilsgebeure in die kerkgebou elke Sondagoggend, is 'n spesifieke verlede in daardie hede onthou met die oog op die toekoms.

So het ek dus voortdurend verskeie weergawes van die verlede deur klank en taal, op my kassetspeler, by konserte en in die erediens en op kampe in daardie dekade van my lewe in herinnering geroep. Gesamentlik het hulle ook anamneties 'n spesifieke toekoms, waarop ek gehoop het, gevorm. Dit was 'n hoop op 'n toekoms waarin die erediens van die kerk en die erediens van die musiekkonsert sal hande vat om die ooglopende diskrepansie waarin ons geleef het, te help oorbrug.

Nietemin, in daardie jare het die alternatiewe Afrikaanse musikante geen aanspraak op God se teenwoordigheid in hulle musiek en optredes gemaak nie. Hulle lirieke, en sommiges se verhoogname, verklap soos reeds aangetoon 'n voortdurende worsteling met godsdiens en spesifiek die vorm van Christelike godsdiens wat hulle voortdurend as 'Calvinisties' tipeer, en selfs sing oor ' $n$ 'Calvinistiese vloek' ${ }^{18}$. Bes moontlik het hulle dit maar net teen 'n soort godsdiens gehad wat slegs die heersende politieke bestel dien en nie ook

16.Die term anamnese verwys na die tydsdimensie binne die sakramentele gebeure waartydens die verlede in die hede onthou word met die oog op die toekoms.

17.Kyk na Serfontein et. al (1976). Benewens die amptelike Psalm- en Gesange-bunde was daar ook in daardie jare ander liederebundels wat gebruik is waarvan veral twee in ons ge die Sing-Onderhierdie een artikel in kaart te bring. Tog word hulle bestaan en invloed hiermee hierdie een artikel in kaart te bring. Tog word hulle bestaan en invloed hiermee

18.Aanhaling afkomstig uit die lied Elmaré van die album Vêr van die ou Kalahari (Le Toit 1987). bevraagteken nie en dus mense as sodanig verslaaf, verblind en korrupteer. ' $n$ Mens sou ook daaroor kon spekuleer of die feit dat ' $n$ hele paar van die kunstenaars se pa's predikante was, iets hiermee te doen gehad het. ${ }^{19}$ Hoe dit ook al sy, hulle musiek laat Noordmans (1939:72) se bekende opmerking in sy boek Liturgie onwillekeurig by 'n mens opkom. Hy meen dat ons nie moet dink 'dat God ook naar de kerk gaat als wij er naar toe gaat'. Hierdie musiek was verseker nie suiwer 'Reformed according to Scripture' soos Old dit stel nie, maar dit het op 'n redelik 'gereformeerde' wyse vrae oopgebreek rakende 'die aard van God se teenwoordigheid' asook 'die aard van die teenwoordige God'. Of laasgenoemde gevolg die eksplisiete bedoeling van die musici en liriekskrywers was, is egter te betwyfel, hoewel dit tog moontlik kan wees. Die wyse waarop ek dit egter saam met die Psalms en Gesange van die erediens toegeëien het, het aan die musiek wel hierdie kwaliteite verleen. My persoonlike beoordeling van my toe-ëiening van die kerkmusiek in die NG Kerk gedurende hierdie jare van ' $n$ apartheidsbewind is nie besonder negatief nie, maar dit is in elke geval nie die vraag wat hierdie artikel probeer beantwoord nie. Die vraag is eerder of hierdie kerkmusiek uit hierdie periode as 'gereformeerd' beskou kan word al dan nie. Indien McKee se dubbele fokus in Gereformeerde aanbidding van pietas en caritas hier weer in herinnering geroep word, dan doen die alternatiewe Afrikaanse musiek-beweging goed met betrekking tot'n doelbewuste klem op caritas.

'n Soort Skriftuurlike ontleding van die lirieke in die Psalmen Gesangebundel (Serfontein et. al 1976) is nie nodig om aan te toon dat daardie lirieke inderdaad 'according to Scripture' was nie ${ }^{20}$, maar of dit 'Reformed according to Scripture' was, is natuurlik ' $n$ heel ander vraag. Die 'aard van God se teenwoordigheid' asook die 'aard van die teenwoordige God' het natuurlik heel anders daar uitgesien as by die alternatiewe Afrikaanse musiek. Daarom sou ek vermoed dat beide soorte ten dele die adjektief 'gereformeerd' waardig is, toegegee dat die een soort dit gretiger as kompliment sal toeëien as die ander. Die musiek van die alternatiewe Afrikaanse-beweging was nie 'according to Scripture' nie, oftewel nie 'n doelbewuste poging om as sodanig die Bybel se boodskap in hulle musiek te vergestalt nie. Hulle musiek was egter inderdaad hermeneuties gesproke eg kontekstueel betrokke binne die Suid-Afrikaanse samelewing van die dag met inagneming van die plek en rol van godsdiens en spesifiek ook die kerk in daardie samelewing. As sodanig was die musiek 'gereformeerd' deurdat dit die, om hulle eie woorde te gebruik, 'Calvinistiese God' en godsdiens help ontmasker het as in die greep van 'n onregverdige politieke bestel. Daarenteen was die kerkmusiek onder bespreking wel doelbewus 'according to Scripture', maar het die hermeneuties kontekstuele kant grootliks ontbreek, sover my geheue my toelaat om daardie belewenisse in herinnering te roep en wanneer ek weer na die liedere se teks kyk. ${ }^{21}$ Die ideaal is 'n model vir die

19.Dit is interessant dat predikantskinders vandag steeds prominent is in die alternatiewe Afrikaanse musiekwêreld.

20. Hier sou teoloë natuurlik kon hare kloof en is heelwat liedere se teks ook daarom in die Liedboek van die kerk (2001) hersien.

21. Hierdie liedere het uiteraard nie in isolasie gefunksioneer nie, maar wel binne die konteks van eredienste. Die argument sou tereg gevoer kon word dat die kontekstuele begronding in die ander elemente van die erediens tereg moes kom, eerder as spesifiek in die liedere en musiek. 
inkulturasie van liturgiese musiek waar bogenoemde twee aspekte kan ontmoet as 'gereformeerd volgens die Skrif', maar die ontwikkeling van so 'n model is nie die bedoeling van hierdie artikel nie, eerder net ' $n$ beklemtoning van die noodsaak daarvan.

\section{Soms is ek nog hy}

Bernoldus Niemand, oftewel die Engelse Wits-student James Phillips, se album waarmee hy die alternatiewe Afrikaanse musiekbeweging as't ware ingelei het, is getiteld Wie is Bernoldus Niemand? Op die DVD dokumentêr oor die Voëlvrybeweging is Philips se cowboy-hoed ook deurgaans so laag oor sy gesig getrek dat slegs sy mond sigbaar is. Vir hom was 'n groot deel van sy deelname aan die beweging blykbaar iets wat aan sy eie identiteit nou gekoppel was. ${ }^{22}$ Identiteit en die worsteling daarmee is ' $n$ deurlopende tema in baie van die musiek van hierdie beweging. Deurgaans is daar ook blyke van 'n worsteling met konflikterende identiteite, soos wat die outeur aangedui het hy self ook beleef het. Daar is tegelykertyd 'n bewustheid van 'n Afrikaner-identiteit en 'n verskeidenheid aspekte wat daarmee saamgaan, soos hierdie reëls uit die lied Boer in beton van Koos Kombuis illustreer:
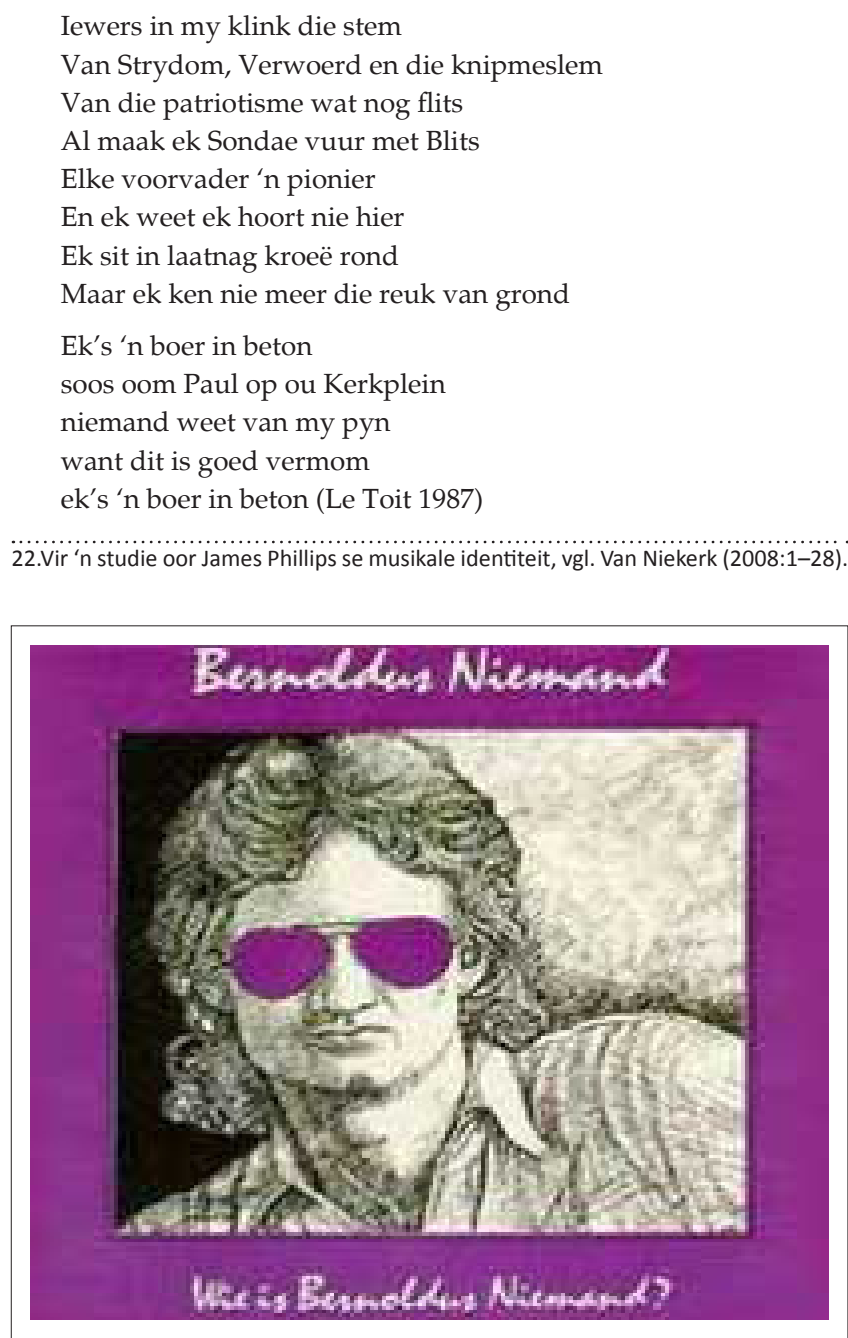

Bron: The South African Rock Encyclopedia, 2012, Bernoldus Niemand (James Phillips). Wie is Bernoldus Niemand?, besigtig 28 Maart 2012, van http://www.rock.co.za/files/jp_niemand. htm

FIGUUR 3: Omslag van die album getiteld Wie is Bernoldus Niemand? vrygestel in 1984, deur Shifty Records.
Ook die anti-establishment identiteit, wat veral gemik was teen die toenmalige politieke bestel van die Nasionale Party, en hoe hulle as kunstenaars vanweë aspekte soos velkleur en moedertaal direk daarmee geassosieer is, is in die musiek uitgedruk. Liedjies wat hierdie tweede aspek goed illustreer, sluit onder andere in Sit dit af! en Energie van Johannes Kerkorrel en die Gereformeerde Blues Band en Hou my vas korporaal van Bernoldus Niemand (The South African Rock Encyclopedia 2012), om maar enkeles uit te sonder.

Identiteit en identiteitsvorming is ook ' $n$ sentrale gegewe in die Christelike godsdiens. Soos reeds aangetoon, is identiteit in Dirkie Smit se verstaan van die begrip 'gereformeerde erediens' nie in lood gegiet nie, maar inteendeel oop en dinamies en voortdurend reformerend. In die gereformeerde kerkmusiek uit hierdie tyd is hierdie tema ook aantoonbaar, alhoewel effens anders as in die alternatiewe Afrikaanse musiek. Christus as sentrale identiteitsmerker werk ook voortdurend vormend in op die lewe van diegene wat in die kerkbanke saamsing. Kern-temas soos sonde, verlossing en dankbaarheid is duidelike identiteitsmerkers in die Psalms en Gesange wat ook op 'n eie wyse(ie?) identiteitsvormend op deelnemers inwerk. ${ }^{23}$

Terwyl ek nou outo-etnografies in my eie verlede delf, kom Bart Nel (Van Melle 1984:199) se weerbarstige uitlating 'ek is nog hy' weer by my op. Ek is inderdaad vandag 16 jaar later nog hy, Casparus Johannes Wepener, met al die gepaardgaande Afrikaanse en Afrikaner-konnotasies wat 'n naam soos myne in 'n sogenaamde nuwe Suid-Afrika oproep. Tog is ek terselfdertyd beslis nie meer hy nie en distansieer ek my in vele opsigte van hom. As Van Wyk Louw se vraende versreëls uit Ballade van die bose hier herhaal kan word:

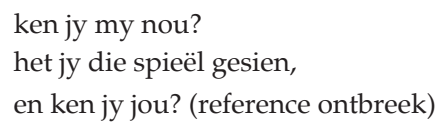

is die spieëls wat by my opkom en waarin ek na antwoorde op hierdie vrae moet gaan soek sowel Paulus se dowwe spieël waarin ek ' $n$ raaiselagtige beeld sien (1 Kor 13:12) as Bernoldus Niemand se reflekterende pers sonbril op die omslag van sy album Wie is Bernoldus Niemand? (The South African Rock Encyclopedia, 2012).

Wat kan 'n mens werklik antwoord op die vrae oor wie jy is en besig is om te word? Dit is moeilike vrae waarmee ' $n$ mens altyd besig bly, maar danksy die vormende invloed van beide soorte 'gereformeerde' musiek uit my jeug, verstaan ek vandag wel iets van Antjie Krog (1995) se versreëls in die gedig Paternoster uit die bundel Gedigte, 1989-1995, te wete:

$$
\begin{aligned}
& \text { ek is } \\
& \text { ek is } \\
& \text { die here hoor my } \\
& \text { 'n vry fokken vrou (p. 66) }
\end{aligned}
$$

In my eie geval is dit eerder:

$$
\begin{aligned}
& \text { ek is } \\
& \text { ek is } \\
& \text { die here hoor my } \\
& \text { (') gereformeerd (') (outeur se eie weergawe) }
\end{aligned}
$$

23.Oor liturgie en identiteitsvorming, kyk ook na Wepener en Pauw (2003) en Wepener (2008). 




Bron: The South African Rock Encyclopedia, 2012, Johannes Kerkorrel, besigtig 28 Maar 2012, van http://www.rock.co.za/legends/90s/kerkorrel_index.html

FIGUUR 4: Omslag van die album getiteld Voëlvry, vrygestel in 1988, deur Shifty Records.

'n besef wat ook, om die outo-etnografiese metodologie konsekwent deur te voer, as antwoord dien op die aanvanklike vraagstelling soos verwoord in die titel van hierdie artikel. ${ }^{24}$

\section{Erkenning \\ Mededingende belange}

Die outeur verklaar dat hy geen finansiële of persoonlike verbintenis het met enige partye wat hom in die skryf van hierdie artikel nadelig kon beïnvloed het nie.

\section{Literatuurverwysings}

Algemene Sinode van die NG Kerk, 1994, 'Riglyne vir kerksang en -musiek', Handelinge van die Algemene Sinode van die NG Kerk 1994, pp. 402-406, Agenda, Nederduitse Gereformeerde Kerk, Suid-Afrika.

Babbie, E. \& Mouton, J., 2001, The Practice of Social Research, With contributions by Payze Vorster Boshoff Prozesky, Oxford University Press, Cape Town.

Bailey, C.A., 1996, A guide to field research, Pine Forge Press, Thousand Oaks.

Bell, C., 1997, Ritual: Perspectives and Dimensions, Oxford University Press, New York.

Capps, D., 1990, Reframing. A New Method in Pastoral Care, Fortress Press, Minneapolis.

Cunnigham, S.J. \& Jones, M., 2005, 'Autoethnography: A tool for practice and education', CHINZ, Proceedings of the 6th ACM SIGCHI New Zealand Chapter's International Conference on Computer-human Interaction: Making $\mathrm{CH}$ Natural, vol. 94, 1-8.

Deist, F., 1997, Vergewe en vergeet? Oor waarheid en versoening in Christelike perspektief, J.L. van Schaik, Pretoria.

Duncan, M., 2004, 'Autoethnography: Critical appreciation of an emerging art', International Journal of Qualitative Methods, 3/4, viewed 27 October 2010 from http://www.ualberta.ca/ iiqm/backissues/3_4/pdf/duncan.pdf.

24.Kyk ook na die hoofstuk getiteld Gespeen van die Boeregeloof? in Müller (2011:43-67)
Grimes, R.L., 1995, Beginnings in Ritual Studies. Revised Edition, University of South Carolina Press, Columbia.

Johnson, C.V., 2005, 'Researching Ritual Action', Studia Liturgia 35(2), 204-220.

Kombuis, K., 2009, Die Tyd van die Kombi's. 'n Persoonlike blik op die Afrikaanse rockrebellie, Human \& Rousseau, Kaapstad.

Krog, A., 1995, Gedigte 1989-1995, Hond, Groenkloof.

Le Toit, A., 1988, Die Bar op De Aar. Ballades, Blues en Bevliegings, TafelbergUitgewers, Kaapstad.

Le Toit, A., 1987, Ver van die ou Kalahari, kassetband, Shifty Studios, Bertsham.

Lukken, G., 1999, Rituelen in overvloed. Een kritische bezinning op de plaats en de gestalte van het christelijke ritueel in onze cultuur, Gooi \& Sticht, Baarn.

McGann, M., 2010, 'Liturgical musical ethnography. Challenges and promise', Jaarboek voor liturgie-onderzoek 26, 83-98.

McKee, E.A., 1995, 'Context, Contours, Contents: Towards a Description of the Classical Reformed Teaching of Worship', The Princeton Seminary Bulletin XVI(2), 172-201.

McKee, E.A., 2003, 'Reformed Worship in the Sixteenth Century', in L. Vischer (ed.), Christian Worship in Reformed Churches Past and present, pp. 3-31, William B. Eerdmans Publishing Company, Grand Rapids.

Müller, J., 2011, Om te mag twyfel. 'n Gelowige se reis, Tafelberg Uitgewers, Kaapstad. Noordmans, O., 1939, Liturgie, Uitgeversmaatschappij Holland, Amsterdam.

Old, H.O., 2002, Worship. Reformed According to Scripture, rev. and expanded edn., Westminster John Knox, Louisville.

Reason, P., 1994, 'Three approaches to participative inquiry', in N.K. Denzin \& Y.S. Lincoln (eds.), Handbook of qualitative research, pp. 327-333, Sage Publications, Thousand Oaks.

Serfontein, W.J.B. (red.), 1976, Die Berymde Psalms en die Evangeliese Gesange, N.G. Kerk-Uitgewers, Kaapstad.

Smit, D., 2009, 'Ontdek die eie aard van die Gereformeerde erediens', in C.J. Wepener \& I.J. van der Merwe (reds.), Ontdekkings in die erediens, pp. 87-107, Lux Verbi. BM, Wellington.

Stephenson, B., 2010, Performing the Reformation. Public Ritual in the City of Luther. Oxford Ritual Studies Series 2, Oxford University Press, Oxford.

Stewart, A., 1998, The ethnographer's method. Qualitative research methods Series 46, Sage Publications, Thousand Oaks.

Stringer, M.D., 1989, 'Liturgy and anthropology: the history of a relationship', Worship 63(6), 503-521.

Stringer, M.D., 1999, On the perception of worship, Birmingham University Press, Birmingham.

The South African Rock Encyclopedia, 2012, Johannes Kerkorrel, viewed 28 March 2012, from http://www.rock.co.za/legends/90s/kerkorrel_index.html

The South African Rock Encyclopedia, 2012, Bernoldus Niemand (James Phillips). Wie is Bernoldus Niemand?, besigtig 28 Maart 2012, van http://www.rock.co.za/files/ jp_niemand.html

Van Melle, J., 1984, Bart Nel, J.L. van Schaik, Pretoria.

Van Niekerk, C., 2008, 'Fathoming the musical identity/identities of James Phillips aka Bernoldus Niemand', S.A. Tydskrif vir Kultuurgeskiedenis 22(1), 1-18.

Wepener, C.J., 2004, 'Van vas tot fees. ' $n$ Ritueel-liturgiese ondersoek na versoening binne Suid-Afrikaanse kultuurkontekste', DTh-Proefskrif, Fakulteit Teologie, Universiteit van Stellenbosch.

Wepener, C.J., 2005, 'Researching Rituals. On the use of participatory action research in liturgical studies', Praktiese Teologie in Suid-Afrika 20(1), 109-127.

Wepener, C.J., 2008, 'Liturgy on the edge of tradition', Praktiese Teologie in Suid-Afrika 23/2, 313-335.

Wepener, C.J., 2009, From fast to feast. A ritual-liturgical exploration of reconciliation in South African cultural contexts, Liturgia Condenda 19, Peeters Pers, Leuven.

Wepener, C.J., 2010, 'Liturgical research in a changing South African socio-cultural (liturgical) landscape: challenges and opportunities for method and theory', in I. Swart, H. Rocher, S. Green \& J. Erasmus (eds.), Religion and Social Development in Post-Apartheid South Africa: Perspectives for Critical Engagement, pp. 403-415, SUN Press, Stellenbosch.

Wepener, C.J. \& Pauw, J.C., 2004, 'Terug na die toekoms - oor die samehang tussen rituele tyd en identiteit', Scriptura 85(1), 110-122. 